\title{
3-Tesla magnetic resonance imaging of the equine brain in healthy horses - Potentials and limitations
}

\author{
Kathrin Stuckenschneiderl, Maren Hellige ${ }^{l}$, Karsten Feige and Hagen Gasse ${ }^{2}$ \\ 1 Klinik für Pferde der Stiftung Tierärztliche Hochschule Hannover \\ 2 Anatomisches Institut der Stiftung Tierärztliche Hochschule Hannover
}

\begin{abstract}
Summary: For evaluating neurological diseases, magnetic resonance imaging (MRI) has been widely recommended as the method of choice in human medicine. It has been proposed as a valuable tool in clinical diagnostics and research projects in veterinary medicine as well. The aim of this study was to elaborate optimal settings appropriate for an examination of the equine brain in a 3-Tesla tomograph within an adequate examination time and with related optimal image quality. A key issue was the evaluation of those neuro-anatomical structures (formations of Grey and White Matter included) which were always clearly recognisable and, as such, were useful orientation landmarks. Furthermore, the average sizes of selected structures were measured in the magnetic resonance images in transversal views. MRI of 11 healthy horses was performed in general anaesthesia. After the examination the horses were euthanised, their heads were fixated by perfusion, the brain was removed and cut either in transversal, dorsal or sagittal slices (approximately 4 mm thick). Photographic images of these slices corresponded to the magnetic resonance images in the equivalent planes. In the anatomical slices, all visible neurological structures (gyri, nuclei, and formations of White Matter) were identified. In the corresponding magnetic resonance images, these structures were evaluated with regard to the image quality (intensity, delineation). Those best visible were proposed as landmarks for orientation. The evaluation of the image quality was performed using a score system. In general, the anatomical slices displayed more details compared to the magnetic resonance images. In the latter, large nuclei - like, e.g. Nucleus caudatus - could always be identified with certainty, whereas small nuclei - like those of the thalamic region or of the area of the Medulla oblongata - could not be identified. The relation between operational effort and benefit was discussed considering the parameters 'acquisition time' (and related duration of general anaesthesia) and 'image quality' (which depended on the selection of sectional planes and matrix sizes, as displayed in the proposed protocols).
\end{abstract}

Keywords: MRI / horse / brain / 3 Tesla / orientation landmarks / diagnostic imaging

\section{3-Tesla-magnetresonanztomographische Untersuchungen des Gehirns gesunder Pferde - Möglichkeiten und Grenzen}

Die Magnetresonanztomographie (MRT) wird in der Humanmedizin als Methode der Wahl zur Bewertung neurologischer Erkrankungen empfohlen und ist ebenso in der tiermedizinischen Diagnostik und Forschung etabliert. Ziel dieser Untersuchung am lebenden Pferd war es, optimale Einstellungen festzulegen, mit denen das Pferdegehirn in einem 3-Tesla-Gerät adäquat, d.h. in angemessener Untersuchungszeit bei optimaler Bildqualität, untersucht werden kann. Im Mittelpunkt stand dabei die Darstellung jener neuroanatomischen Strukturen einschließlich Formationen aus Graver und Weißer Substanz, die stets sicher erkennbar und deshalb als Landmarks zur Orientierung im Pferdegehirn geeignet waren. Außerdem wurden die durchschnittlichen Größen von einigen ausgewählten Strukturen im MRT-Bild transversaler Schnittebenen gemessen. Die MRT-Untersuchung erfolgte bei 11 Pferden in Allgemeinanästhesie. Im Anschluss wurden die Pferde euthanasiert, der Kopf perfusionsfixiert, die Gehirne entnommen und entweder transversal, dorsal oder sagittal in ca. $4 \mathrm{~mm}$ dicke Scheiben geschnitten. Fotografische Abbildungen dieser Schnitte korrespondierten mit MRT-Bildern in den entsprechenden Schnittebenen. In den anatomischen Abbildungen wurden alle sichtbaren neuroanatomischen Strukturen (Gyri, Nuclei, Formationen der Weißen Substanz) identifiziert. Anschließend wurden in den MRT-Bildern diese Strukturen hinsichtlich ihrer Abbildungsqualität (Intensität, Abgrenzbarkeit) evaluiert; die am besten erkennbaren wurden als Landmarks zur Orientierung festgelegt. Die Bildqualität der MRT-Aufnahmen wurde mit Hilfe eines Scoring-Systems bestimmt. Generell zeigten die anatomischen Schnitte mehr Details als die MRT-Aufnahmen. Im MRT-Bild waren große Kerne, wie der Nucleus caudatus, stets eindeutig erkennbar. Kleine Nuclei, z. B. jene der Thalamusregion oder der kaudalen Region des Hirnstammes, waren nicht darstellbar. Ein Aufwand-Nutzen-Vergleich unter Berücksichtigung der Parameter "Akquisitionszeit" (damit verbunden die notwendige Daver der Anästhesie) und "Bildqualität” (in Abhängigkeit verschiedener Einstellungen) wurde diskutiert in Hinblick auf die empfohlenen Untersuchungsprotokolle.

Schlüsselwörter: MRT / Pferd / Gehirn / 3 Tesla / Orientierungs-Landmarks / bildgebende Diagnostik

Citation: Stuckenschneider K., Hellige M., Feige K., Gasse H (2014) 3-Tesla magnetic resonance imaging of the equine brain in healthy horses - Potentials and limitations. Pferdeheilkunde 30, 657-670

Correspondence: Prof. Dr. Hagen Gasse, Anatomisches Institut, Tierärztliche Hochschule Hannover, Bischofsholer Damm 15, 30173 Hannover, E-Mail: hagen.gasse@tiho-hannover.de

\section{Introduction}

In human and small animal medicine, magnetic resonance imaging (MRI) is the method of choice when it comes to evaluating neurological diseases (Hecht and Adams 2010). According to Holmes (2013), this is also true for equine patients. MRI has been used as a diagnostic tool in several neurologically affected horses, like: Features of nigropallidal encephalomalacia (Sanders et al. 2001), cerebral abscess, encephalomalacia, nigropallidal encephalomalacia, internal hydrocephalus, otitis media and interna (Ferrell et al. 2002), metastatic brain abscesses in horses with strangles (Spoormakers et al. 2003), brain abscess in a filly (Audigié et al. 2004), brainstem meningioma in a pony (Dyson et al. 2007), ocular angiosarcoma in a pony (Bischofberger et al. 2008), cholesterol granuloma (Maulet et al. 2008), ependymoma (Leser et 
al. 2013), retrobulbar meningioma (Naylor et al. 2010), cerebellar abiotrophy (Pongratz et al. 2010, Cavalleri et al. 2013), external and an internal hydrocephalus (Oey et al. 2011), posttraumatic epilepsy (Müller et al. 2011), Chiari malformation in a foal (Lempe et al. 2012), features of closed head trauma in two foals (De Zani et al. 2013). Anatomical studies of the equine brain in MRI have been performed in foals (Chaffin et al. 1997) and in adult horses (Arencibia et al. 2001), however, with varying settings: Chaffin et al. (1997) used a very low field strength of 0.35 Tesla; Arencibia et al. (2001) examined a post mortem head (removed from the neck), using a magnet of 1.5 Tesla. Tucker and Sampson (2007) recommended protocols applicable for examinations of the head in a 1-Tesla tomograph. Until now, no protocols have been elaborated for examinations of the equine brain with a field strength as high as 3 Tesla, and no evaluations of the image quality by means of a score system are available from such investigations. Therefore, it was the aim of this study (1) to elaborate optimal settings appropriate for an examination of the equine brain in a 3-Tesla tomograph within an adequate examination time and with related optimal image quality; (2) to evaluate those neuro-anatomical structures which were always clearly recognisable and, as such, were useful orientation landmarks; (3) to measure the average sizes of selected structures in the magnetic resonance images in transversal views.

\section{Material and methods}

Eleven horses $(6$ Württemberg and 2 Hanoverian warmblood horses, 1 Trakehner horse, 1 Trotter and 1 Frisian horse) aged between 4 and 9 years $(5.2 \pm 1.8)$ and with a body weight between $498 \mathrm{~kg}$ und $607 \mathrm{~kg}(543.9 \pm 35.4)$ underwent a standard general and a special neurological examination. They did not suffer from neurological diseases. For MRI, the horses underwent general anaesthesia. They were sedated with acepromazine (Vetranquil ${ }^{\circledR} 1 \%$, Albrecht, Aulendorf, Germany; $0.03 \mathrm{mg} / \mathrm{kg}$ i.m.), xylazine (Xylavet ${ }^{\circledR} 20 \mathrm{mg} / \mathrm{ml}, \mathrm{cp}$ pharma, Burgdorf, Germany; $0.5-0.8 \mathrm{mg} / \mathrm{kg}$ i.v.) and butorphanol (Alvegesic ${ }^{\circledR}$ vet. $10 \mathrm{mg} / \mathrm{ml}, \mathrm{cp}$-pharma, Burgdorf, Germany; $0.025 \mathrm{mg} / \mathrm{kg}$ i.v.). The general anaesthesia was induced by ketamine (Narketan ${ }^{\circledR} 100 \mathrm{mg} / \mathrm{ml}$, Vetoquinol, Ravensburg, Germany; $2.2 \mathrm{mg} / \mathrm{kg}$ i.v.) and midazolam (Midazolam $5 \mathrm{mg} / \mathrm{ml}$, Braun, Tuttlingen, Germany; $0.05 \mathrm{mg} / \mathrm{kg}$ i.v.) and maintained with isofluran in oxygen (Isofluran, cp-pharma, Burgdorf, Germany). A very deep general anaesthesia was chosen in order to avoid spontaneous movement and to ensure that the horses did not regain consciousness after the examination.

All horses were examined in the magnetic resonance tomograph Achieva 3.0T X-series ${ }^{\circledR}$ (Koninkliike Philips Electronics, Eindhoven, The Netherlands) in dorsal recumbency with four

Table 1 Protocol for MRI of the equine brain at a field strength of 3 Tesla, slice thickness $5 \mathrm{~mm}(\mathrm{n}=3)$ or $4 \mathrm{~mm}(\mathrm{n}=6)$. / Protokoll der magnetresonanztomographischen Untersuchung der Gehirne von Pferden bei einer Feldstärke von 3 Tesla, Schnittdicke $5 \mathrm{~mm}(n=3)$ oder $4 \mathrm{~mm}(n=6)$.

\begin{tabular}{|c|c|c|c|c|c|c|c|c|c|}
\hline Plane & Sequence & $\begin{array}{c}\text { TR } \\
\text { (msec) }\end{array}$ & $\begin{array}{c}\mathrm{TE} \\
(\mathrm{msec})\end{array}$ & $\mathrm{FA}$ & FOV & Matrix size & $\begin{array}{c}\text { Slice/ Thickness } \\
(\mathrm{mm})\end{array}$ & $\begin{array}{l}\text { Gap } \\
(\mathrm{mm})\end{array}$ & Time* \\
\hline $3 \mathrm{D}$ & TIW, GRE & 8 & 4 & 8 & 280 & $320 \times 320$ & $145 / 1.1$ & 0 & $0: 10: 27$ \\
\hline Trans & T2W, TSE & 9000 & 80 & 90 & 190 & $432 \times 432$ & $31 / 5$ & 1 & 0:08:42 \\
\hline Dors & T2W, TSE & 8000 & 80 & 90 & 210 & $640 \times 640$ & $24 / 5$ & 0.5 & $0: 04: 48$ \\
\hline Sag & T2W, TSE & 8000 & 80 & 90 & 240 & $704 \times 704$ & $17 / 5$ & 0.5 & $0: 08: 32$ \\
\hline Trans & T2W, TSE & 9000 & 80 & 90 & 190 & $432 \times 432$ & $33 / 4$ & 1 & $0: 12: 54$ \\
\hline Dors & T2W, TSE & 9000 & 80 & 90 & 190 & $432 \times 432$ & $33 / 4$ & 1 & $0: 12: 54$ \\
\hline Sag & T2W, TSE & 9000 & 80 & 90 & 190 & $432 \times 432$ & $33 / 4$ & 1 & $0: 14: 42$ \\
\hline Trans & FLAIR & 10000 & 140 & 90 & 180 & $512 \times 512$ & $36 / 4.2$ & 0.4 & 0:08:00 \\
\hline Trans & DWI, SE & 4000 & 69 & 90 & 180 & $160 \times 160$ & $38 / 4$ & 0.4 & 0:03:30 \\
\hline
\end{tabular}

Dors: Dorsal, DWI: Diffusion weighted imaging, FA: Flip angle, FLAIR: Fluid attenuated inversion recovery, FOV: Field of view, GRE: Gradient echo, T1W: T1-weighted, T2W: T2-weighted, TE: Echo time, TR: Repetition time, Trans: Transversal, TSE: Turbo-spin-echo, Sag: Sagittal, SE: Spin-echo, 3D: Three-dimensional,

*Hours:Minutes:Seconds / Dors: Dorsal, DWI: Diffusionsgewichtete Bildgebung, FA: Anregungswinkel, FLAIR: Fluid attenuated inversion recovery

(Messtechnik zur Unterdrückung des Liquorsignals), FOV: Bildfeld, GRE: Gradientenecho, T1W: T1-gewichtet, T2W:T2-gewichtet, TE: Echozeit, TR: Repetitionszeit,

Trans: Transversal, TSE: Turbo-Spin-Echo, Sag: Sagittal, SE: Spin-Echo, 3D: Dreidimensional, *Stunden:Minuten:Sekunden

\begin{tabular}{|c|c|c|c|c|c|c|c|c|c|}
\hline Plane & Sequence & $\begin{array}{c}\text { TR } \\
\text { (msec) }\end{array}$ & $\begin{array}{c}\text { TE } \\
\text { (msec) }\end{array}$ & FA & FOV & Matrix size & $\begin{array}{c}\text { Slice/Thickness } \\
(\mathrm{mm})\end{array}$ & $\begin{array}{l}\text { Gap } \\
(\mathrm{mm})\end{array}$ & Time* \\
\hline $3 D$ & T1W, GRE & 13 & 6 & 8 & 200 & $1024 \times 1024$ & $250 / 0.6$ & 0 & $1: 19: 58$ \\
\hline Trans & T2W, TSE & 5000 & 80 & 90 & 140 & $1024 \times 1024$ & $33 / 4.0$ & 1 & 1:08:15 \\
\hline Dors & T2W, TSE & 5000 & 80 & 90 & 190 & $896 \times 896$ & $24 / 4.0$ & 0.6 & $0: 53: 30$ \\
\hline Sag & T2W, TSE & 5000 & 80 & 90 & 180 & $1008 \times 1008$ & $28 / 4.0$ & 0.6 & $0: 45: 10$ \\
\hline
\end{tabular}

Dors: Dorsal, FA: Flip angle, FOV: Field of view, GRE: Gradient echo, T1W: T1-weighted, T2W: T2-weighted, TE: Echo time, TR: Repetition time, Trans: Transversal, TSE: Turbo-spin-echo, Sag: Sagittal, 3D: Three-dimensional, *Hours:Minutes:Seconds / Dors: Dorsal, FA: Anregungswinkel, FOV: Bildfeld, GRE: Gradientenecho, T1W: T1-gewichtet, T2W:T2-gewichtet, TE: Echozeit, TR: Repetitionszeit, Trans: Transversal, TSE: Turbo-Spin-Echo, Sag: Sagittal, 3D: Dreidimensional,

*Stunden:Minuten:Sekunden 

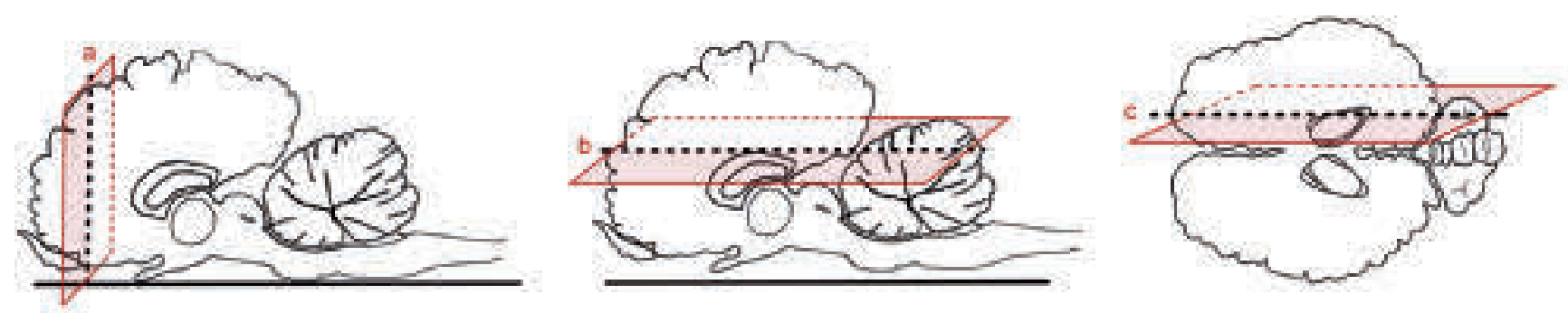

Fig. 1 Graphical representation of the three sectional planes, i.e. transversal (a), dorsal (b), sagittal (c) planes, of anatomical sections and MRI. / Graphische Darstellung der drei Schnittebenen, d.h. transversale (a), dorsale (b), sagittale (c) Schnittebenen, für anatomische Schnitte und magnetresonanztomographische Bilder.

flexible surface coils (two SENSE Flex M Coils ${ }^{\circledR}$ and two SENSE Flex L Coils ${ }^{\circledR}$; both Koninklijke Philips Electronics, Eindhoven, The Netherlands) around their heads. The imaging protocol comprised a T2-weighted (T2W) sequence in all three planes (i.e. dorsal, transversal, sagittal), a 3D-T1-weighted (3D T1W) sequence, a Fluid-attenuated-inversion-recovery sequence (FLAIR sequence), and a Diffusion-weighted-imaging sequence (DWI sequence) with slice thicknesses of $4 \mathrm{~mm}$ (9 horses), $5 \mathrm{~mm}$ (3 horses), with different matrix sizes and with different data acquisition times (tables 1 and 2).

At the end of the imaging procedure all horses were - still in general anaesthesia - euthanised with pentobarbital (Euthadorm ${ }^{\circledR} 400 \mathrm{mg} / \mathrm{ml}$, cp-pharma, Burgdorf, Germany; $30-40 \mathrm{mg} / \mathrm{kg}$ i.v.). The heads were perfused with $10 \%$ formalin; the brains were removed from the brain case after one day, embedded in $20 \%$ gelatin and cooled for another day. The brains were cut in either transversal (5 brains), dorsal (3 brains) or sagittal (3 brains) slices ( $4 \mathrm{~mm}$ thick) - corresponding to the planes of the magnetic resonance images (Fig. 1). Magnetic resonance images and anatomical slices were compared, i.e. anatomical structures were identified and labelled in the pictures. The anatomical terms were applied according to the latest edition of the Nomina Anatomica Veterinaria (2012). Some terms were named with reference to descriptions by Böhme (2004); they are marked by adding an asterisk * to the term.

The image quality of the T2- and T1 - weighted images (T1W, T2W) was evaluated by applying a scoring system (table 3). A total of 14 points could be assigned to an image. Images with a score of 10 points or more were rated as being of good quality, images with a score between 9 and 5 points had a sufficient quality and images with a score of less than 5 points were not evaluated.

Selected structures, which were clearly delineable in transversal T1-and T2- weighted images were determined: The length of each structure was measured first; then - at an

Table 3 Scoring system (parameters and related scores) for the evaluation of the image quality of T2-and T1-weighted images. Auswertungsbogen (Parameter und entsprechende Punktzahlen) für die Beurteilung der Qualität von T1 - und T2-gewichteten Aufnahmen.

\begin{tabular}{|c|c|c|c|}
\hline Parameter & Score & Parameter & Score \\
\hline Delineation between White and Grey Matter & & Intensity of signal of the cerebrospinal liquor * & \\
\hline Clearly delineated & 4 & Hypointense signal in T1W & 1 \\
\hline Not clearly delineated & 2 & Hyperintense signal in T2W & 1 \\
\hline \multirow[t]{2}{*}{ No delineation } & 0 & Iso-/hypointense signal in T1W & 0 \\
\hline & & Iso-/hypointense signal inT2W & 0 \\
\hline Recognisability of selected nuclei /selected areas of nuclei & & Recognisability of N. opticus ${ }^{* *}$ and $\mathrm{N}$. trigeminus ${ }^{* * *}$ & \\
\hline Nucl. caud. clearly delineated & 1 & N. opticus identifiable & 1 \\
\hline Nucl. caud. not/not clearly & 0 & N. opticus not identifiable & 0 \\
\hline Capsula interna delineated & 1 & N. trigeminus identifiable & 1 \\
\hline Capsula interna not delineated & 0 & N. trigeminus not identifiable & 0 \\
\hline Image sharpness $* * * *$ & & Artefacts & \\
\hline Clear image & 1 & No artefact & 1 \\
\hline Grainy image & 0 & One or more delineated artefacts & 0 \\
\hline Regularity of the signal & & $\begin{array}{l}\text { Artefact covering large areas of brain } \\
\text { (e.g. whole hemisphere) }\end{array}$ & n.e. \\
\hline Regular & 1 & & \\
\hline Irregular & 0 & & \\
\hline Large areas of the brain (e.g. cerebellum) not visable ${ }^{* * * * *}$ & n.e. & & \\
\hline
\end{tabular}

${ }^{*}$ Compared to cerebral or cerebellar cortex; ${ }^{* *}$ Next to the brain stem; ${ }^{* * *}$ At lateroventral side of the brain; ${ }^{* * * * S u b j e c t i v e ~ i m p r e s s i o n ; ~}{ }^{* * * * *}$ Because of an either too strong or too low signal intensity; n.e.: Image not evaluable; Nucl. caud.: Nucleus caudatus

*Im Vergleich zur Klein- oder Großhirnrinde; ${ }^{* *}$ Nahe am Hirnstamm; ${ }^{* * *}$ An der lateroventralen Seite des Gehirns; ${ }^{* * * *}$ Subjektiver Eindruck; ${ }^{* * * * *}$ Aufgrund entweder zu starker oder zu schwacher Signalintensität; n.e.: Bild nicht auswertbar; Nucl. caud.: Nucleus caudatus 
angle of $90(+/-1)$ degrees - the width was measured. The normal distribution of values measured in corresponding hemispheres (right/left) of all animals was tested by the Kolmogorov-Smirnov-Test. Values of the left and right hemispheres were compared with the paired t-test, and confirmed. Differences concerning dimensions and signal-intensities were not significant between the hemispheres. Consequently, the values of bilateral structures (in right and left hemispheres) were pooled and treated as one sample. From each sample, mean values and standard deviations were calculated (Excel ${ }^{\circledR}$ 2010, Microsoft ${ }^{\circledR}$ Corporation Redmont, Washington, USA; Prism ${ }^{\circledR}$ Version 5.01 for Windows; GraphPad Software, La Jolla, USA).

Finally, the intensities of the selected structures were visually compared to either the cerebral or cerebellar cortex (reference parameters) and rated as either hypointense, or isointense, or hyperintense.

The horses were treated in the Clinic for Horses, University of Veterinary Medicine Hannover.

\section{Results}

The instrumental settings, and the acquisition times varied according to the kind and amount of chosen sectional planes. For instance, all acquisition times necessary to acquire the T1W- and T2W-images in transversal, dorsal, sagittal planes plus FLAIR- and DWI-sequences (table 1) could add up to about 60 minutes; another setting with higher matrix sizes (table 2) required a total acquisition time of almost 4 hours (without FLAIR- and DWI-sequences).

The quality of the images created with different protocols did not differ markedly when viewed on the display screen (table 4): The total score of $\mathrm{T} 1$-weighted images of 8 horses was 12 $( \pm 2)$. Transversal T2-weighted images of 7 horses had scores of $13( \pm 1)$, dorsal T2-weighted images of 6 horses had scores of $13( \pm 1)$, and T2-weighted sagittal images of 6 horses had scores of $12( \pm 2)$. Consequently, all of the created MRI were rated as being of good quality on the display screen.
Magnetic resonance images in the sagittal plane (Fig. $2 \mathrm{~A}-\mathrm{C}$ ) represented equivalents of brain slices cut in the median (or slightly paramedian) plane. They were intended to give an overview of the whole brain. The brain 's ventricular system Ventriculus lateralis, tertius, quartus, and the Aqueductus mesencephali - was clearly outlined. Different profiles of the Corpus callosum were distinct orientation landmarks. The same was true for the Colliculus rostralis and Colliculus caudalis of the Lamina tecti mesencephali. The Cerebellum (with its Arbor vitae) as well as the Pons and the Medulla oblongata could be clearly distinguished.

Transversal magnetic resonance images of the rostral part of the brain (Fig. $3 \mathrm{~A}-\mathrm{C}$ ) were dominated by the different structures of the telencephalon. Particularly remarkable were the components of the Corpus striatum, which could be clearly distinguished in every image: Its Nucleus caudatus and the Capsula interna served as distinct landmarks as they could be reliably identified in anatomical slices as well as in magnetic resonance images. In the anatomical slice, any other component of the Corpus striatum could be marked in addition: Putamen and Pallidum (conjointly representing the Nucleus lentiformis) could be differentiated as well as Nucleus accumbens, Claustrum, Capsula externa, and Capsula extrema. However, in the magnetic resonance images, the Nucleus accumbens could only be seen on T2-weighted images, and the identification of Putamen and Pallidum was also more difficult. In magnetic resonance images, Claustrum and Capsula extrema could not be seen, but Capsula externa and Capsula interna served as good orientation landmarks.

Images in the transversal plane taken further caudally (Fig. 4 A-C) showed structures of the Tel-, Di- and Mesencephalon. Different components of the Hippocampus region were the characteristic features of these brain areas because many of them could be identified on both anatomical and magnetic resonance images: Pars retrocommissuralis hippocampi (the Hippocampus proper according to Nomina Anatomica Veterinaria, NAV, 2012), Pes hippocampi, Gyrus dentatus, Sulcus hippocampi, and Gyrus parahippocampalis. The Gyrus callosus (not an official term of the NAV, and not a true part of the Hippocampus) was very useful as an orientation land-

Table 4 Scoring points (maximum 14) for the evaluation of the quality of MRI. / Scoring-Punkte (maximal 14) für die Bewertung der MRTBildqualität.

\begin{tabular}{ccccc}
\hline Horse & T1W, 3D & T2W, Trans & T2W, Dors & T2W, Sag \\
\hline 1 & 14 & 14 & 13 & 12 \\
2 & 10 & 13 & n.p. & 12 \\
3 & 8 & n.e. & 12 & 12 \\
4 & 14 & 13 & n.p. & n.p. \\
5 & 12 & 13 & n.p. & n.p. \\
6 & 13 & 13 & 13 & 12 \\
7 & 13 & n.p. & 13 & n.p. \\
9 & n.p. & 13 & 13 & n.e. \\
10 & 13 & n.e. & n.p. & n.e. \\
\hline 11 & n.p. & n.p. & & \\
\hline
\end{tabular}

Scores $\geq 10$ : Good image quality, scores 9-5: Sufficient image quality, scores < 5: Not evaluable (n.e.), n.p.: Not performed, Dors: Dorsal, Sag: Sagittal,

T1W: T1-weighted, T2W: T2-weighted. / Scores 2 10: Gute Bildqualität, Scores 9-5: Ausreichende Bildqualität, Scores < 5: Nicht auswertbar (n.e.), n.p.: Nicht durchgeführt, Dors: Dorsal, Sag: Sagittal, T1W: T1-gewichtet, T2W: T2-gewichtet 

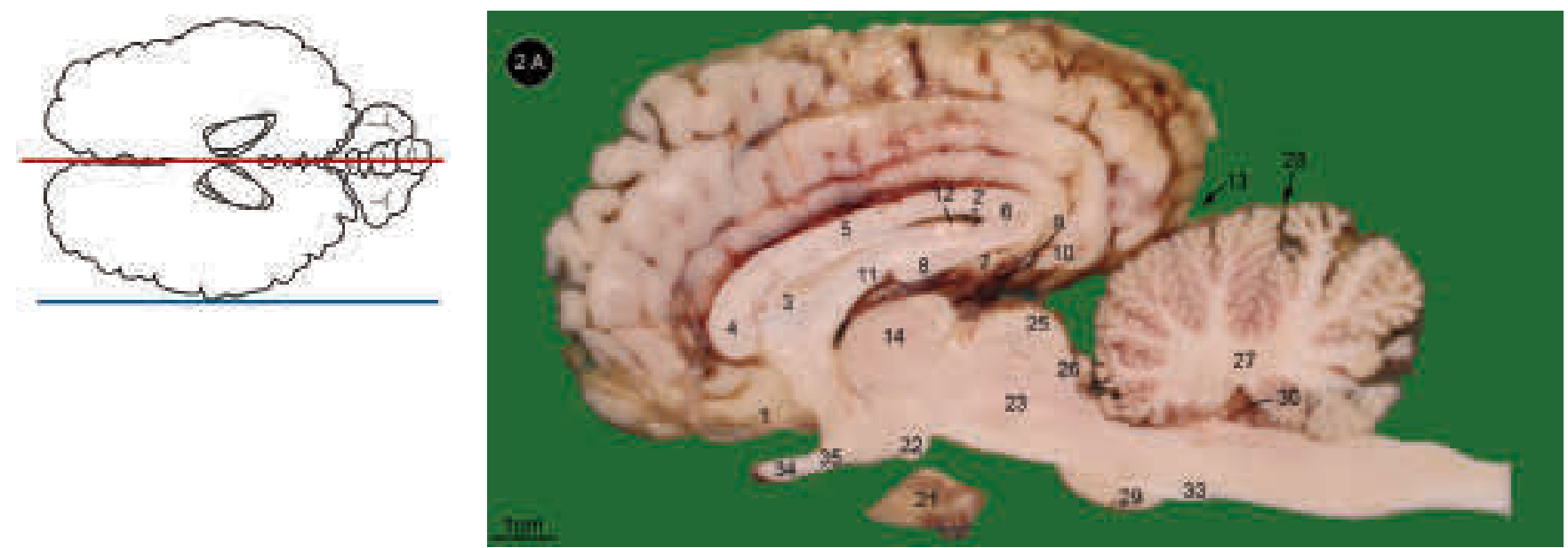

Fig. 2 (A) Anatomical section, slightly paramedian, (B) corresponding T2weighted MRI, (C) corresponding T1weighted MRI of an equine brain in a median/paramedian, i.e. sagittal sectional plane. / Anatomischer Schnitt, leicht paramedian, (B) korrespondierendes T2gewichtetes, (C) korrespondierendes T1gewichtetes magnetresonanztomographisches Bild eines Pferdegehirns in medianer/paramedianer, d. h. sagittaler Schnittebene.

1: Trigonum olfactorium, 2: Ventriculus lateralis (Pars centralis), 3: Septum telencephali, 4: Genu corporis callosi, 5: Truncus corporis callosi, 6: Splenium corporis callosi, 7: Gyrus callosus (Böhme 2004), 8: Gyrus dentatus (rostral Area/rostraler Bereich - Tuberculum gyri dentati [Böhme 2004]), 9: Sulcus hippocampi, 10: Gyrus parahippocampalis, 11: Corpus fornicis, 12: Crus fornicis, 13: Fissura transversa cerebri, 14: Adhesio interthalamica, 15: Glandula pinealis, 16: Recessus suprapinealis, 17: Recessus opticus, 18: Foramen interventriculare, 19: Ventriculus tertius, 20: Infundibulum with/mit Pars cava infundibuli, 21: Hypophysis, 22: Corpus mamillare, 23: Pedunculus cerebri (Tegmentum mesencephali), 24: Aqueductus mesencephali, 25: Tectum mesencephali (Lamina tecti, Colliculus rostralis), 26: Tectum mesencephali (Lamina tecti, Colliculus caudalis), 27: Cerebellum (Corpus medullare), 28: Fissura prima, 29: Pons, 30: Ventriculus quartus, 31: Velum medullare rostrale, 32: Velum medullare caudale, 33: Corpus trapezoideum, 34: N. opticus, 35: Chiasma opticum, a: A. cerebri rostralis, b: Branches of/Äste der A. cerebri caudalis, c: A. corporis callosi, d: A. communicans rostralis, e: A. communicans caudalis
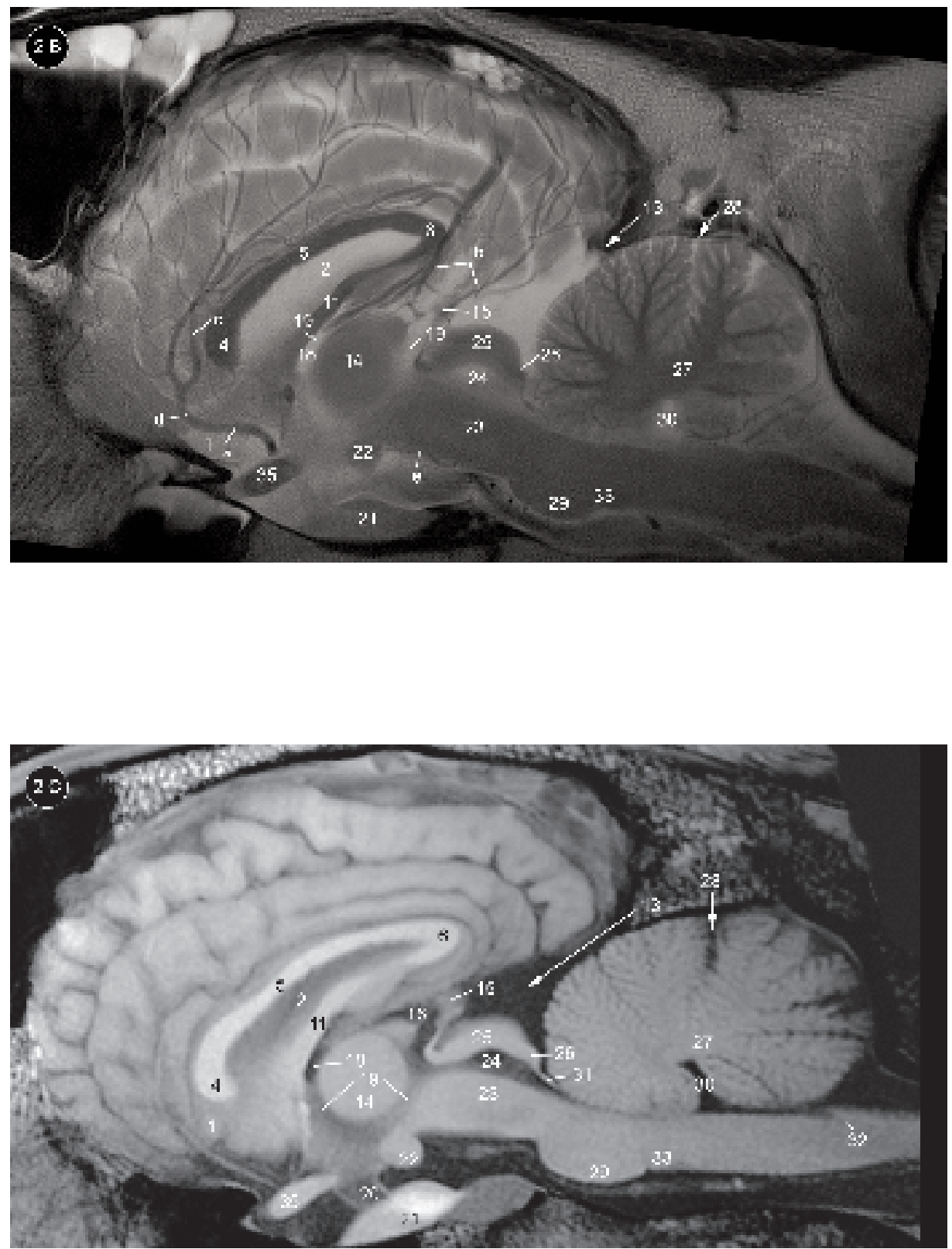

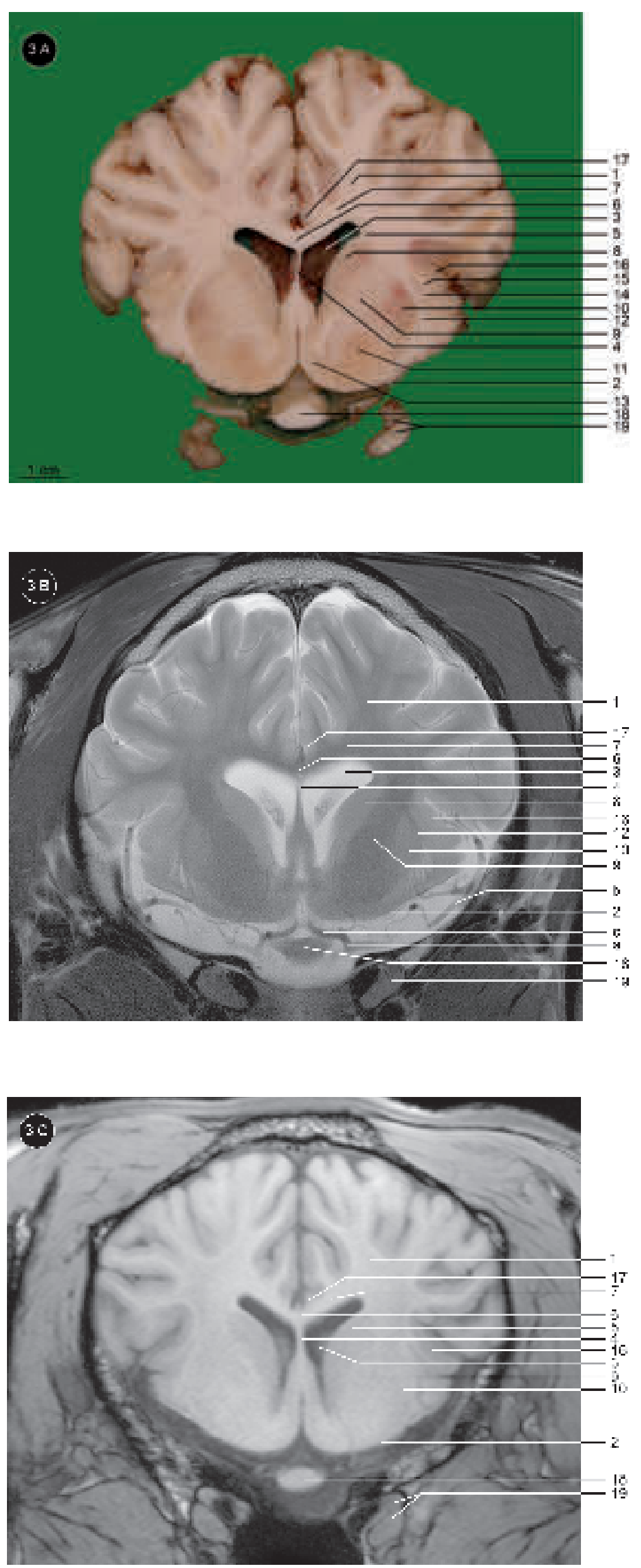

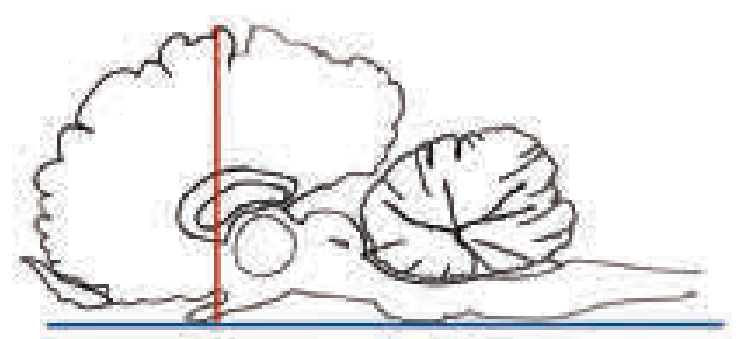

Fig. 3 (A) Anatomical section, (B) corresponding T2weighted MRI, (C) corresponding T1-weighted MRI of an equine brain in a transversal sectional plane.

(A) Anatomischer Schnitt, (B) korrespondierendes T2gewichtetes, (C) korrespondierendes Tl-gewichtetes magnetresonanztomographisches Bild eines Pferdegehirns in einer transversalen Schnittebene.

1: Centrum semiovale, 2: Tuberculum olfactorium, 3: Ventriculus lateralis (Pars centralis, Plexus choroideus), 4: Septum telencephali, 5: Stratum griseum subependymale (Böhme 2004), 6: Truncus corporis callosi, 7: Radiatio corporis callosi, 8: Corpus striatum (Nucleus caudatus), 9: Corpus striatum (Capsula interna), 10: Corpus striatum (Putamen), 11 : Corpus striatum (Pallidum), 12: Corpus striatum (Capsula externa), 13: Corpus striatum (Nucleus accumbens), 14: Corpus striatum (Claustrum), 15: Corpus striatum (Capsula extrema), 16: Insula, 17: Pars supracommissuralis hippocampi (Indusium griseum), 18: Chiasma opticum, 19: N. trigeminus, $a$ : $A$. cerebri rostralis, $b$ : Branches of/Äste $\operatorname{der} \mathrm{A}$. cerebri media, c: A. communicans rostralis 

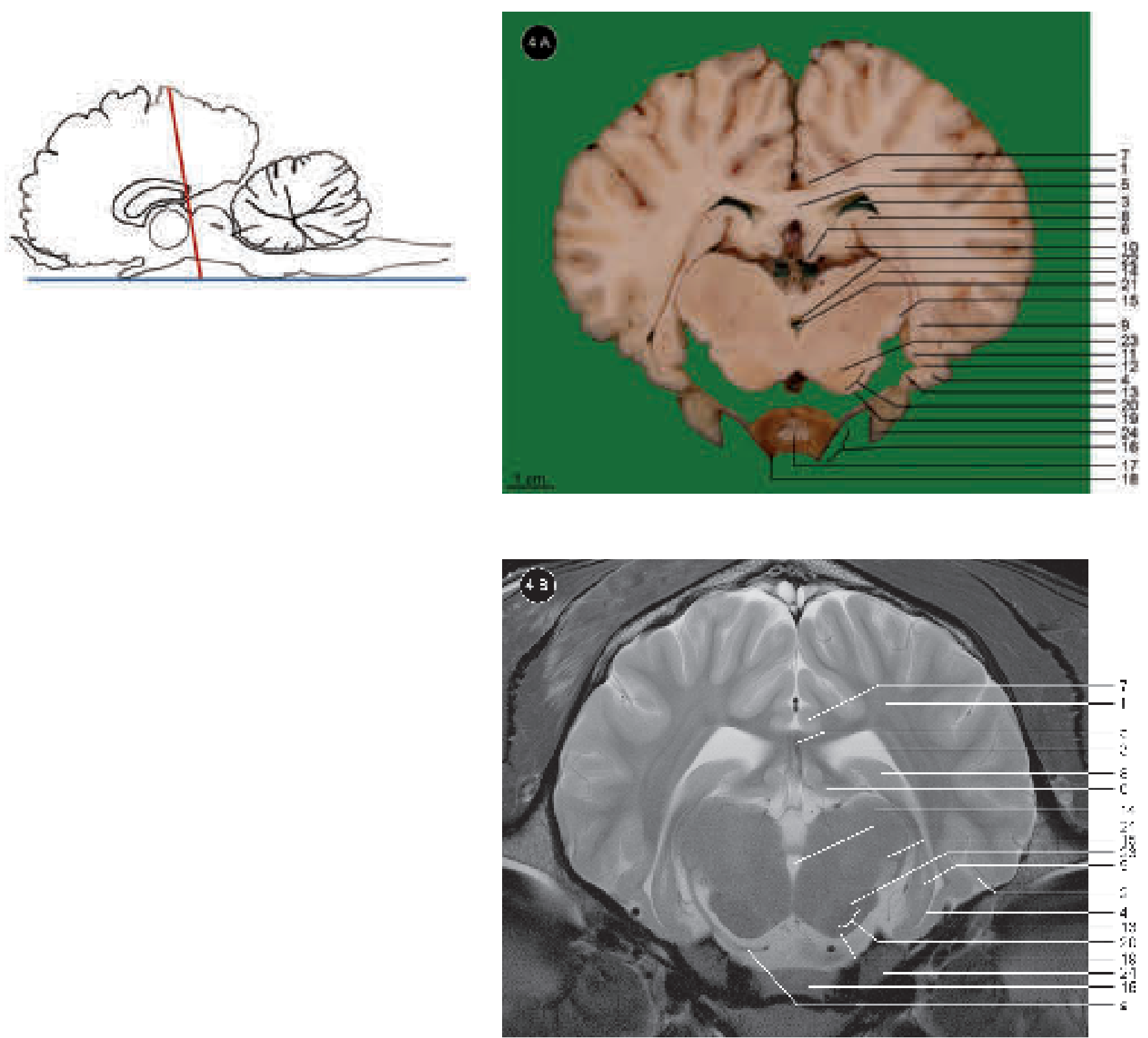

Fig. 4 (A) Anatomical section, (B) corresponding T2-weighted MRI, (C) corresponding T1-weighted MRI of an equine brain in a transversal sectional plane.

(A) Anatomischer Schnitt, (B) korrespondierendes T2gewichtetes, (C) korrespondierendes T7-gewichtetes magnetresonanztomographisches Bild eines Pferdegehirns in einer transversalen Schnittebene.

1: Centrum semiovale, 2: Sulcus rhinalis lateralis, 3: Ventriculis lateralis (Pars centralis), 4: Ventriculus lateralis (Cornu temporale), 5: Splenium corporis callosi, 6: Gyrus callosus (Böhme 2004), 7: Pars supracommissuralis hippocampi (Indusium griseum), 8: Pars retrocommissuralis hippocampi, 9: Pes hippocampi, 10: Gyrus dentatus (dorsal end/dorsales Ende - Tuberculum gyri dentati [Böhme 2004]), 11: Gyrus dentatus (ventral end/ventrales Ende), 12: Sulcus hippocampi, 13: Gyrus parahippocampalis, 14: Corpus geniculatum laterale, 15: Corpus geniculatum mediale, 16: Hypophysis with/mit: 17: Neurohypohysis, 18: Adenohypophysis, 19: Pedunculus cerebri (Crus cerebri), 20: Pedunculus cerebri (Tegmentum mesencephali), 21: Aqueductus mesencephali, 22: Substantia grisea centralis, 23: Nucleus ruber, 24: N. trigeminus, a: A. cerebri caudalis

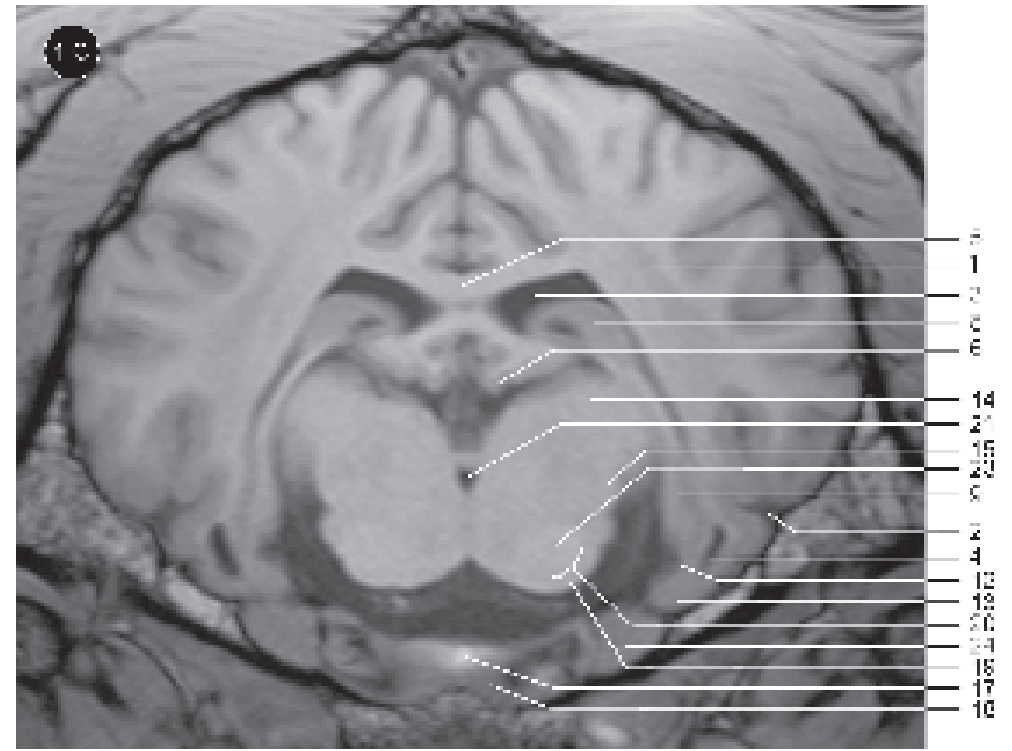



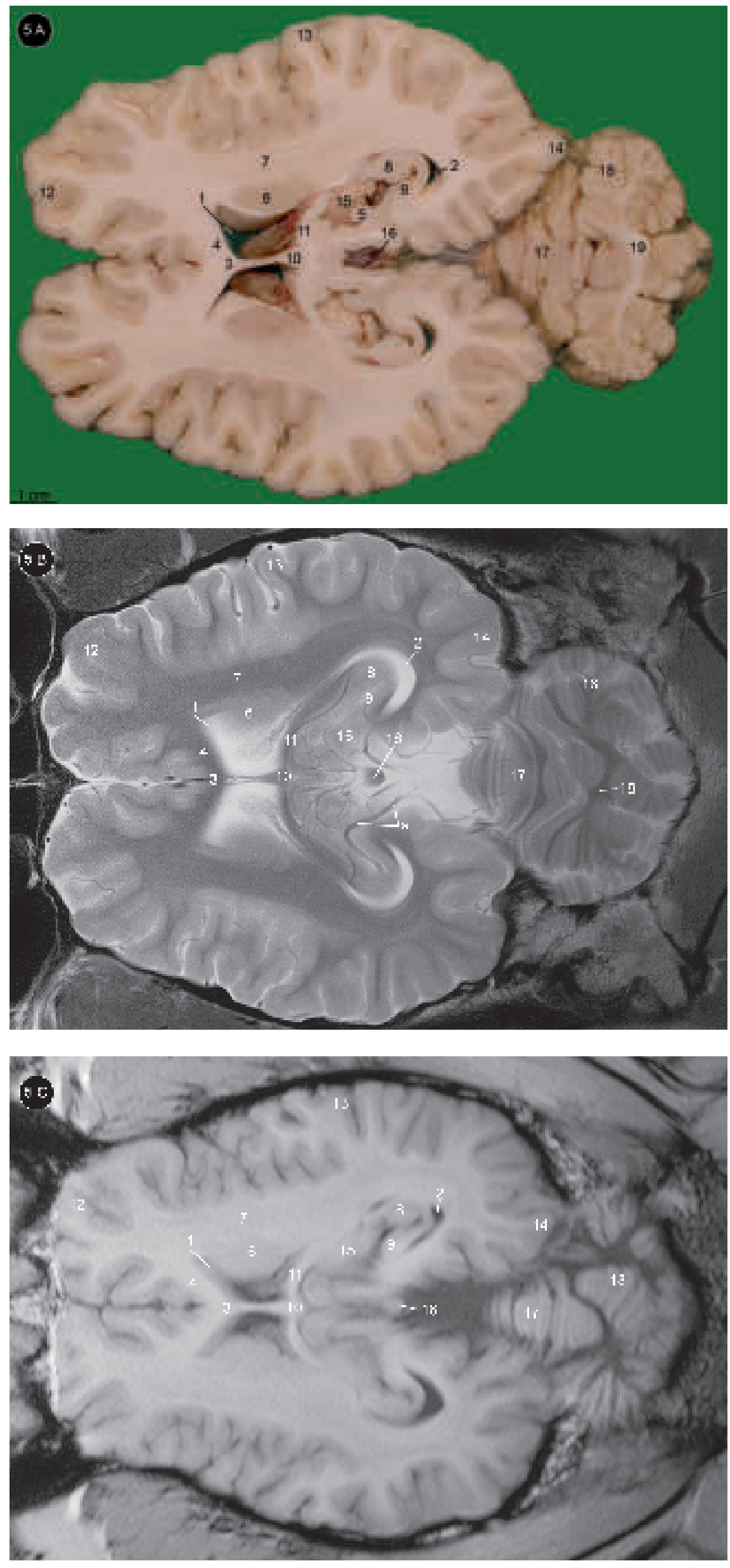

Fig. 5 (A) Anatomical section, (B) corresponding T2-weighted MRI, (C) corresponding T1weighted MRI of an equine brain in a dorsal sectional plane.

(A) Anatomischer Schnitt, (B) korrespondierendes T2-gewichtetes, (C) korrespondierendes T1gewichtetes magnetresonanztomographisches Bild eines Pferdegehirns in einer dorsalen Schnittebene.

1: Ventriculus lateralis (Cornu rostrale), 2: Ventriculus lateralis (Cornu temporale), 3: Genu corporis callosi, 4: Radiatio corporis callosi, 5: Gyrus callosus (Böhme 2004), 6: Corpus striatum (Nucleus caudatus), 7: Corpus striatum (Capsula interna), 8: Pars retrocommissuralis hippocampi, 9: Gyrus dentatus (central area/mittlerer Bereich), 10: Corpus fornicis, 11: Crus fornicis, 12: Neopallium (Cortex frontalis), 13: Neopallium (Cortex temporalis), 14: Neopallium (Cortex occipitalis), 15: Thalamus, 16: Glandula pinealis, 17: Cerebellum (Vermis), 18: Cerebellum (Hemispherium), 19: Cerebellum (Corpus medullare), a: Branches of/Äste $\operatorname{der} \mathrm{A}$. cerebri caudalis 

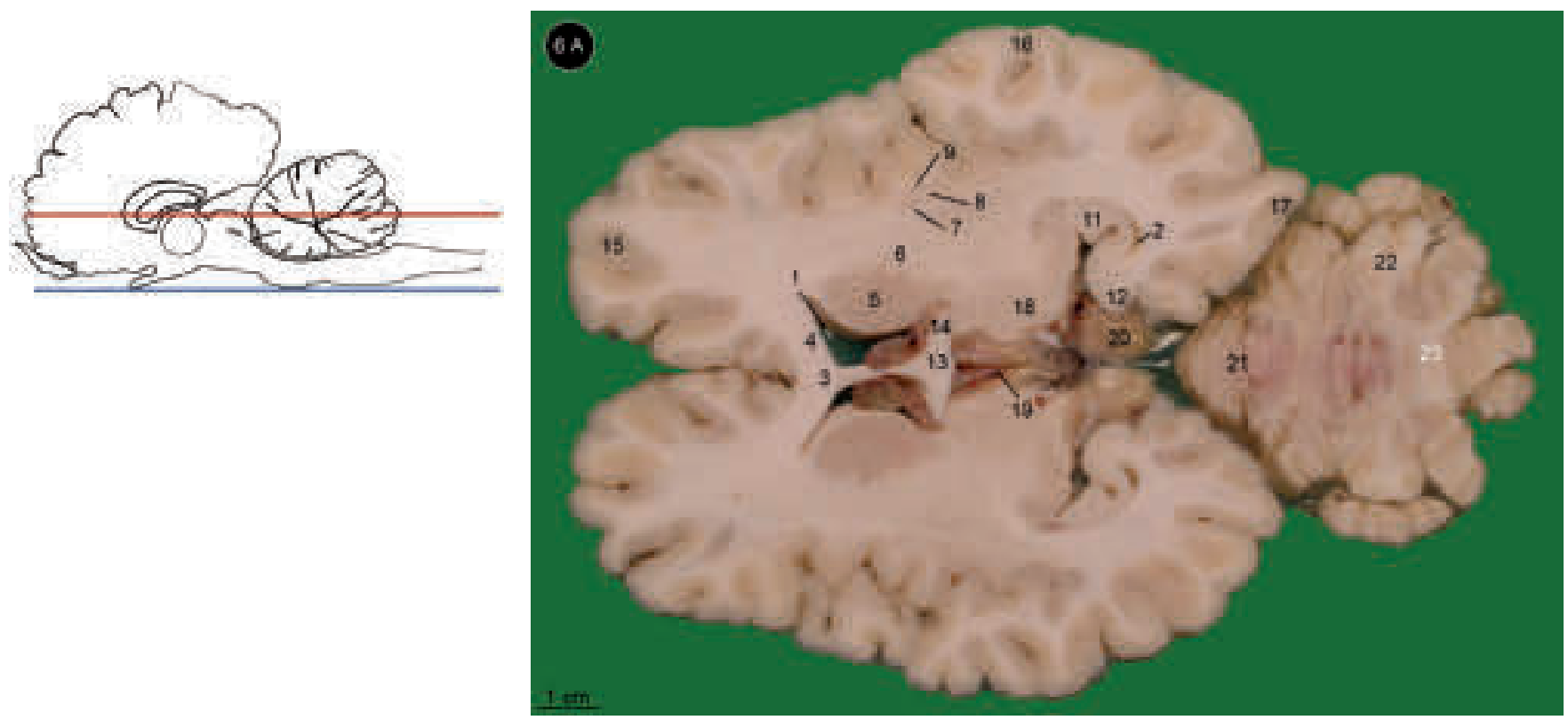

Fig. 6 (A) Anatomical section, (B) corresponding T2-weighted MRI, (C) corresponding $T 1$-weighted MRI of an equine brain in a dorsal sectional plane.

(A) Anatomischer Schnitt, (B) korrespondierendes T2-gewichtetes, (C) korrespondierendes Tl-gewichtetes magnetresonanztomographisches Bild eines Pferdegehirns in einer dorsalen Schnittebene.

1: Ventriculus lateralis (Cornu rostrale), 2: Ventriculus lateralis (Cornu temporale), 3: Genu corporis callosi, 4: Radiatio corporis callosi, 5: Corpus striatum (Nucleus caudatus), 6: Corpus striatum (Capsula interna), 7: Corpus striatum (Capsula externa), 8: Corpus striatum (Claustrum), 9: Corpus striatum (Capsula extrema), 10: Insula, 11: Pars retrocommissuralis hippocampi, 12: Gyrus dentatus (central area/mittlerer Bereich), 13: Corpus fornicis, 14: Crus fornicis, 15: Neopallium (Cortex frontalis), 16: Neopallium (Cortex temporalis), 17: Neopallium (Cortex occipitalis), 18: Thalamus, 19: Glandula pinealis, 20: Tectum mesenephali (Lamina tecti, Colliculus rostralis), 21: Cerebellum (Vermis), 22: Cerebellum (Hemispherium), 23: Cerebellum (Corpus medullare), a: Branches of/Äste der A. cerebri caudalis
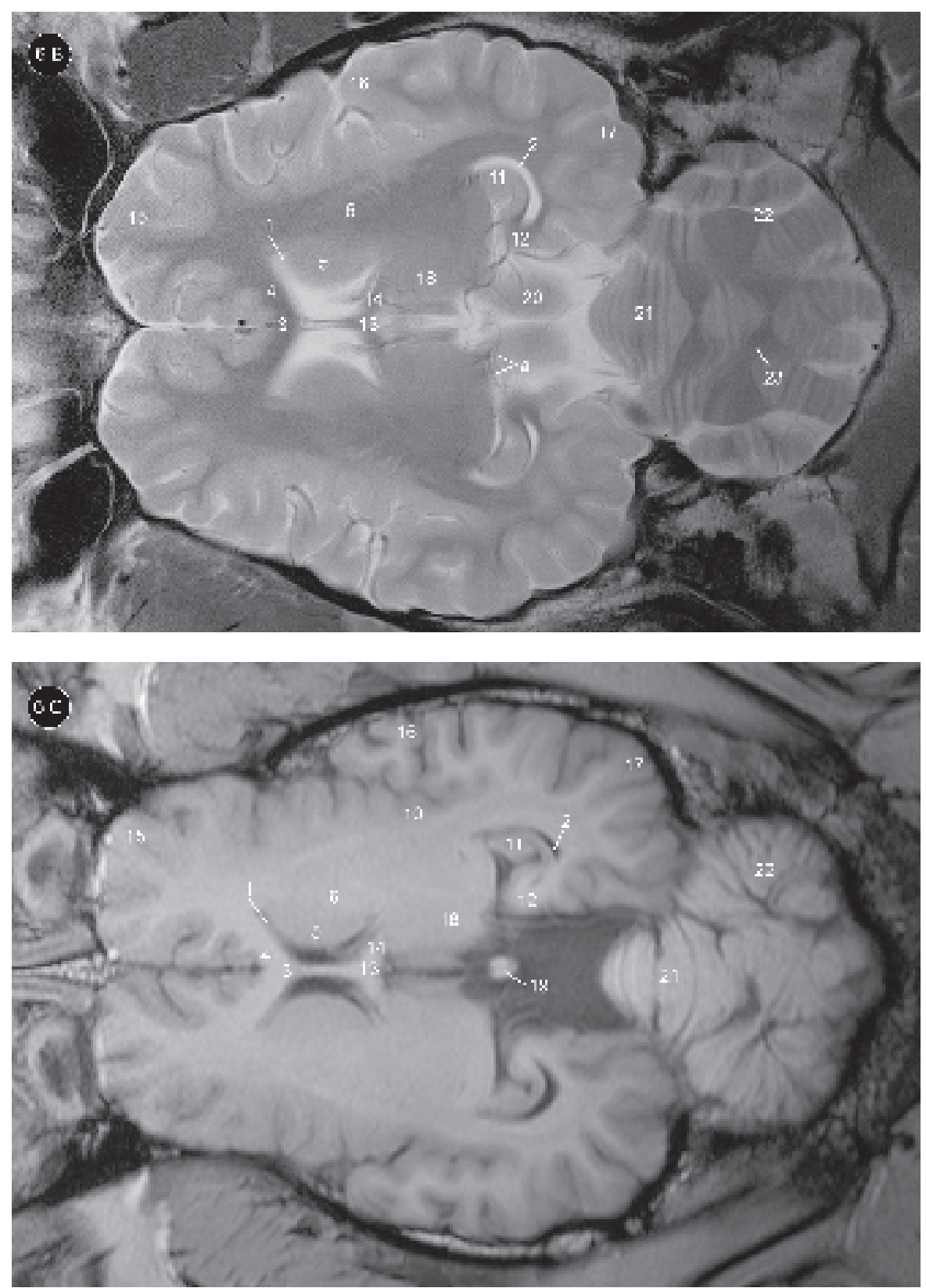
Table 5 Selection of brain structures depicted on T2- and T1-weighted MRI (important landmarks printed in bold letters). / Auswahl von darstellbaren Gehirnstrukturen in T1- und T2-gewichteten MRT-Bildern (wichtige Orientierungslandmarks in Fettdruck)

\begin{tabular}{|c|c|c|c|c|c|c|}
\hline 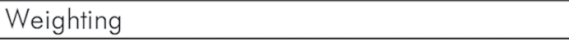 & $\mathrm{T} 2 \mathrm{~W}$ & $\mathrm{~T} 2 \mathrm{~W}$ & $\mathrm{~T} 2 \mathrm{~W}$ & $\mathrm{~T} 1 \mathrm{~W}$ & TIW & $\mathrm{TIW}$ \\
\hline Plane & Trans & Dors & Sag & Trans & Dors & Sag \\
\hline \multicolumn{7}{|l|}{ Structure } \\
\hline Bulbus olfactorius & + & + & + & + & + & + \\
\hline Lobus piriformis & + & + & & + & + & \\
\hline Sulcus rhinalis lateralis & + & + & + & + & + & + \\
\hline Corpus amygdaloideum & + & + & & & + & \\
\hline Ventriculus lateralis & + & + & + & + & + & + \\
\hline Septum telencephali & + & + & + & + & + & + \\
\hline Genu corporis callosi & + & + & + & + & + & + \\
\hline Truncus corporis callosi & + & + & + & + & + & + \\
\hline Splenium corporis callosi & + & + & + & + & + & + \\
\hline Gyrus callosus* & + & & & + & & \\
\hline Nucleus caudatus & + & + & + & + & + & + \\
\hline Capsula interna & + & + & + & + & + & + \\
\hline Putamen & + & + & & + & + & \\
\hline Pallidum & + & & & + & & \\
\hline Nucleus accumbens & + & & & & & \\
\hline Capsula externa & + & + & & + & + & \\
\hline Pars supracommissuralis hippocampi & + & & & + & & \\
\hline Pars retrocommissuralis hippocampi & + & + & + & + & + & + \\
\hline Gyrus dentatus & + & + & + & + & + & + \\
\hline Gyrus parahippocampalis & + & + & + & + & + & + \\
\hline Sulcus hippocampi & + & + & & + & + & \\
\hline Pes hippocampi & + & + & & + & + & \\
\hline Columna fornicis & + & + & & + & + & \\
\hline Corpus fornicis & & + & & & + & \\
\hline Tractus opticus & + & + & + & + & + & + \\
\hline Adhesio interthalamica & + & & + & + & & + \\
\hline Nuclei thalami & + & + & & + & + & \\
\hline Corpus geniculatum laterale & + & + & & + & + & \\
\hline Corpus geniculatum mediale & + & + & + & + & + & + \\
\hline Habenula & + & & & + & & \\
\hline Glandula pinealis & + & + & + & + & + & + \\
\hline Foramen interventriculare & & + & + & & + & + \\
\hline Ventriculus tertius & + & + & + & + & + & + \\
\hline Infundibulum, Pars cava & + & & & + & & \\
\hline Tuber cinereum & + & & & + & & \\
\hline Neurohypophysis & + & + & + & + & + & + \\
\hline Adenohypophysis & + & + & + & + & + & + \\
\hline Corpus mamillare & + & & + & + & & + \\
\hline Pedunculus cerebri, Tegmentum mesencephali & + & & & + & & \\
\hline Pedunculus cerebri, Crus cerebri & + & & & + & & \\
\hline Aqueductus mesencephali & + & + & + & + & + & + \\
\hline Nucleus ruber & + & & & + & & \\
\hline Lamina tecti, Colliculus rostralis & + & + & + & + & + & + \\
\hline Lamina tecti, Colliculus caudalis & + & + & + & + & + & + \\
\hline Vermis cerebelli & + & + & & + & + & \\
\hline Hemispherium cerebelli & + & + & + & + & + & + \\
\hline Pons & + & + & + & + & + & + \\
\hline Ventriculus quartus & + & + & + & + & + & + \\
\hline Velum medullare rostrale & + & & + & + & & + \\
\hline Pedunculus cerebellaris rostralis & + & & & + & & \\
\hline Pedunculus cerebellaris medius & + & & & + & & \\
\hline Nuclei vestibulares & + & & & + & & \\
\hline Pyramis & + & & + & + & & + \\
\hline Velum medullare caudale & & & + & & & + \\
\hline N. opticus & + & + & + & + & + & + \\
\hline Chiasma opticum & + & + & + & + & + & + \\
\hline N. trigeminus & + & + & + & + & + & + \\
\hline Ganglion trigeminale & + & + & + & + & + & + \\
\hline N. facialis & + & + & + & + & + & + \\
\hline N. vestibulocochlearis & + & + & + & + & + & + \\
\hline
\end{tabular}

+ Structure could be identified, Dors: Dorsal, T1W: T1-weighted, T2W: T2-weighted, Sag: sagittal, Trans: transversal

+ Struktur war zu identifizieren, Dors: Dorsal, T1W: T1-gewichtet, T2W: T2-gewichtet, Sag: sagittal, Trans: transversal 
mark. The Hypophysis was clearly separated into Neuro- and Adenohypophysis. In T1-weighted images, the Neurohypophysis was extremely bright.

In images in the dorsal plane (Fig. $5 \mathrm{~A}-\mathrm{C}$ ) all structures mentioned above were present in the same plane. They showed components of the Corpus striatum, and of the Hippocampus region. Anatomical slices in this plane were slightly superior as far as the amount of visible details was concerned; for instance, the Gyrus callosus was only visible in the anatomical slice.

More ventrally, in images in the dorsal plane (Fig. $6 \mathrm{~A}-\mathrm{C}$ ), structures of the Corpus striatum again were dominant features. In this plane, anatomical slices were clearly superior in showing details of this important complex: Nucleus caudatus, Claustrum, Capsula interna, Capsula externa, and Capsula extrema could be identified, but in the magnetic resonance images only Nucleus caudatus and Capsula interna were clearly visible. Parts of the Hippocampus were clearly distinguishable. The Ventriculi laterales and the Cerebellum too could be easily identified.

Comparing magnetic resonance images and anatomical slices, the latter showed more details in general, which often could be clearly distinguished from the adjacent tissue areas. However, magnetic resonance images did display several important landmarks in all sectional planes. These landmarks (table 5) served well for orientation as their presence enabled the viewer to deduce invisible structures.

The performance of measurements required the selections of appropriate sectional planes (table 6, Fig. 7). The values varied markedly particularly in structures with diffuse outlines and asymmetrical shapes - like, e.g. Nucleus caudatus.

\section{Discussion}

The horses in this study formed a homogenous group of samples of the equine population with regard to age and body mass. The performance of the MRI examinations in vivo was a key requirement as post-mortem autolytic processes in the brain are known to start early (Dahme et al. 2007). Moreover, characteristic in vivo signals are absent due to the post-mortem cessation of blood flow, (Kretschmann and Weinrich 2003), so that some examinations, like DWI-sequences, are not applicable in post-mortem specimens.

For MRI, all horses in this study underwent general anaesthesia due to the above mentioned reasons and because the examination with the used magnetic resonance tomograph required a recumbent position of the animals under examination. Consequently, such prerequisites cause higher effort, costs, and risks for the patient when compared, e.g., to orthopaedic examinations which - in increasing numbers (Mitchell et al. 2006) - are performed in standing horses.

A standing position of the horse is not appropriate for the MRI examination of the brain due to several reasons, like exposition to noise, or relatively long acquisition times as shown in the present study.

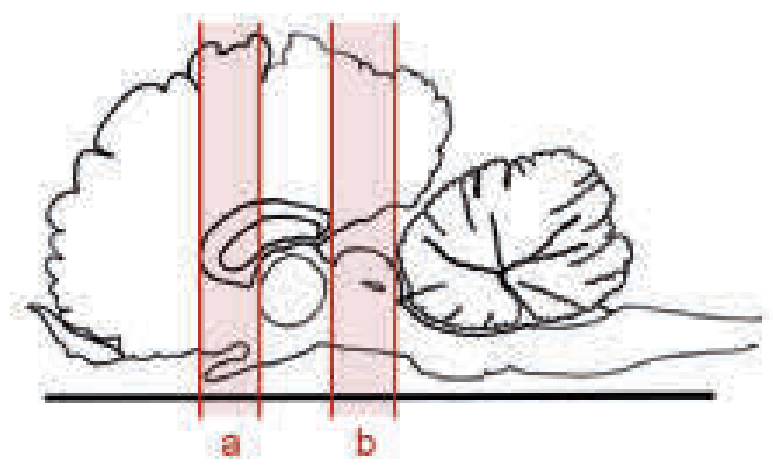

Fig. 7 Graphical representation of the two sectional areas (a and b) from which transversal MRI were selected for the measurements of neuroanatomical structures.

Graphische Darstellung der beiden Schnittbereiche (a und b), aus denen magnetresonanztomographische Querschnittbilder für die Messungen neuroanatomischer Strukturen ausgewählt wurden.

Table 6 Dimensions $(\mathrm{mm}$ ) of selected brain structures (mean values \pm standard deviations, $\mathrm{X} \pm \mathrm{SD}$ ) measured in two regions (region a and $\mathrm{b}$, as indicated in figure 7) comprising the respective transversal sections.

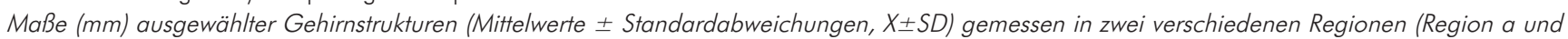
$b$, wie in Abbildung 7 dargestellt), welche die entsprechenden transversalen Schnitte enthalten.

\begin{tabular}{|c|c|c|c|c|c|c|}
\hline Structure & $\begin{array}{l}\text { T2-weighted (T2W)/ } \\
\text { T1-weighted (T1W) }\end{array}$ & $\begin{array}{l}\text { Maximal length } \\
\qquad(X \pm S D)\end{array}$ & $\begin{array}{l}\text { Minimal length } \\
\qquad(X \pm S D)\end{array}$ & $\begin{array}{l}\text { Maximal width } \\
\qquad(X \pm S D)\end{array}$ & $\begin{array}{l}\text { Minimal width } \\
\qquad(X \pm S D)\end{array}$ & Intensity* \\
\hline Nucleus caudatus ${ }^{a}$ & $\mathrm{~T} 2 \mathrm{~W}$ & $26.66 \pm 3.04$ & $19.85 \pm 4.01$ & $9.38 \pm 1.07$ & $6.13 \pm 1.78$ & 2 \\
\hline Nucleus caudatus ${ }^{a}$ & TIW & $25.28 \pm 1.47$ & $15.70 \pm 5.63$ & $9.39 \pm 0.74$ & $5.72 \pm 1.91$ & 2 \\
\hline Capsula interna $^{a}$ & $\mathrm{~T} 2 \mathrm{~W}$ & $31.92 \pm 2.24$ & $29.86 \pm 1.67$ & $9.35 \pm 0.67$ & $7.75 \pm 0.74$ & 1 \\
\hline Capsula interna $^{a}$ & TIW & $27.70 \pm 2.35$ & $26.35 \pm 2.33$ & $11.47 \pm 2.93$ & $8.82 \pm 0.75$ & 3 \\
\hline N. opticus ${ }^{a}$ & $\mathrm{~T} 2 \mathrm{~W}$ & $4.26 \pm 0.38$ & $3.68 \pm 0.47$ & $8.62 \pm 1.05$ & $5.61 \pm 1.03$ & $1-2$ \\
\hline N. opticus ${ }^{a}$ & TIW & $4.90 \pm 0.40$ & $3.99 \pm 0.33$ & $7.91 \pm 0.43$ & $5.78 \pm 0.50$ & 3 \\
\hline $\begin{array}{l}\text { Aqueductus } \\
\text { mesencephalib }\end{array}$ & $\mathrm{T} 2 \mathrm{~W}$ & $6.62 \pm 0.85$ & $3.24 \pm 0.82$ & $6.57 \pm 0.57$ & $2.77 \pm 0.46$ & 1 \\
\hline $\begin{array}{l}\text { Aqueductus } \\
\text { mesencephalib }\end{array}$ & TIW & $6.18 \pm 0.51$ & $2.98 \pm 0.50$ & $6.29 \pm 0.57$ & $2.92 \pm 0.47$ & 3 \\
\hline
\end{tabular}

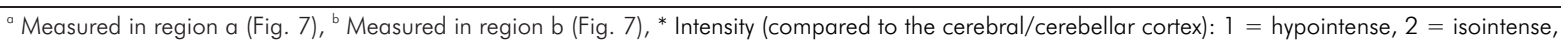
3 = hyperintense; T1W: T1-weighted, T2W: T2-weighted / ${ }^{a}$ Gemessen in Region a (Abb. 7), ' ${ }^{b}$ Gemessen in Region b (Abb. 7), * Intensität (im Vergleich zur Großhirn-/ Kleinhirnrinde): 1 = hypointens, 2 = isointens, 3 = hyperintens, T1W: T1-gewichtet, T2W: T2-gewichtet 
Higher field strengths (like 3 Tesla used in this study) are known to correspond with higher noise level (SchwarzmüllerErber and Silberstein 2010) and may therefore cause artefacts due to auditive stimuli. Related provoked movements together with spontaneous movements - of the animal may cause additional risks for staff and equipment. In consideration of these aspects, high-field-strength MRI of the brain cannot be recommended to be performed on a standing horse.

Depending on the different settings of this study (e.g. with high matrix sizes, several sectional planes, and additional DWI- and FLAIR-sequences), the acquisition times varied markedly between 61 and 261 minutes. These data emphasise again the importance of general anaesthesia. However, the risk of sudden death of a horse during general anaesthesia starts to increase from minute 61 ; the highest risk exists when the general anaesthesia lasts for more than 241 minutes (Johnston et al. 1995).

The parameter 'image quality' is a crucial point for the consideration of effort, risks, and benefits. In this study, MRI created with the highest matrix sizes did not display a markedly better image quality. Scores of 13 (out of 14) or 11 (out of 14) were reached, which was not substantially superior to those of MRI created with the lower matrix sizes. The relatively low score of horse number 3 ( 8 points) may be due to suboptimal positioning of the animal during examination. Considering all relevant parameters (i.e. time of anaesthesia related to acquisition time, and image quality), the settings as displayed in table 1 are recommended for the examination of the equine brain with a 3-Tesla magnet leading to a total examination time of about 60 minutes, and resulting in good quality images.

There is a strong wish to further improve image quality and thereby increase the diagnostic value (Deistung et al. 2013), leading - especially in human medicine - to the development of very strong magnets, which facilitated the use of high-field systems. Currently, in human medicine, 1.5-Tesla systems are the clinical standard, but more and more 3-Tesla systems are used. In the year 2011, already $20 \%$ of all magnetic resonance tomographs used a field strength of 3 Tesla (Anonymus 2013).

Even 7-Tesla systems and 9.4-Tesla systems have been developed (Anonymus 2013). Their actual use is for experimental purposes in research projects, but the expectation is that an increase in field strength will yield a higher signal-to-noiseratio (SNR) and - due to this - a better image quality (Weishaupt et al. 2009). Different studies in human medicine have confirmed this assumption; e.g. in the field of neurodiagnostic research, Haltaufderheide (2009) compared the delineation of cranial nerves at 1.5 and 3 Tesla. In her study, the image quality was significantly better at 3 Tesla, especially when it came to detecting structures which were difficult to assess, like small cranial nerves, and blood vessels (Haltaufderheide 2009). These findings were supported by studies of Hause (2011), who compared the delineation of the intermediofacialis nerve and its branches in different settings. Small branches (e.g. N. petrosus minor or N. stapedius) could be depicted significantly better at the field strength of 3 Tesla, and there was a significant increase in the SNR with increasing field strength (Hause 2011).
Accordingly, in the study on the equine brain presented in this article, the amount of anatomical details seen in MRI (e.g. important areas like the Corpus striatum or the Hippocampus region) was higher than in previous investigations (Chaffin et al. 1997, Arencibia et al. 2001) which had been performed with a lower field strength. Chaffin et al. (1997) used a field strength of only 0.35 Tesla, Arencibia et al. (2001) applied 1.5 Tesla (on a removed head, not in a living horse). The differences in field strength and the ex vivo situation may be the major items to explain the inferior image quality when compared to our 3-Tesla study in vivo.

The further improvement of image quality with regard to the delineation of small tissue areas (nuclei) may be desirable when measurements in MRI are intended. A clear demarcation of nuclei in MRI was often difficult or impossible to achieve even in the 3-Tesla MRI of this study. This was not unexpected, because aggregations of neuronal cells are commonly known to have less distinct outlines than those structures - like ventricles - which per se have clear surface borderlines. This fact should be taken into account when interpreting the measurement data presented in this study. Not all visible structures were measured in cases when their outlines were too diffuse. The data listed must be related only to the respective sectional plane in which they were measured. Consequently, they represent indicative values rather than standard values of the entire size of the respective structure.

The White Matter was a very potential guide to distinguish nuclei which were poorly outlined. The formations of White Matter appeared as distinct, often clearly demarcated lines and, hence, served as valuable orientation landmarks.

The identification of even small nuclei is of great interest, depending on the clinical indication, as has been emphasised by Deistung et al. (2013). However, for their study on the human brainstem - where a multitude of essential nuclei is settled - a 7-Tesla system and different imaging techniques (quantitative susceptibility mapping and track-density imaging) were used. Even though such systems do not appear applicable in equine medicine right now, such experiments indicate that attempts to elucidate the potentials and limitations of MRI-imaging of the brain have not reached their final limit yet.

\section{Acknowledgements}

The authors thank Dr. Peter Dziallas, Clinic for Small Animals, University of Veterinary Medicine Hannover, for his technical support with the acquisition of MRI. Special thanks are due to Mrs. Gudrun Wirth, Institute of Anatomy, University of Veterinary Medicine Hannover, for her most meticulous preparation of the illustrations.

\section{Animal welfare statement}

The study was performed in agreement with the ethical guidelines of the law of animal welfare approved by the Lower Saxony State Office for Consumer Protection and Food Safety, LAVES, approval No. 08/1622. 


\section{Conflict of interest statement}

The authors confirm that no conflict of interest existed when preparing and performing this study.

\section{References}

Anonymus (2013) 2.09.2013: http://www.imp.uni-erlangen.de/ $\mathrm{mri} / \mathrm{pdf} /$ roentgenkongress.pdf

Arencibia A., Vazquez J. M., Ramirez J. A., Ramirez G., Vilar J. M., Rivero M. A., Alayon S., Gil F. (2001) Magnetic resonance imaging of the normal equine brain. Vet. Radiol. Ultrasound 42, 405-409

Audigié F., Tapprest J., George C., Didierlaurent D., Foucher N., Faurie F., Houssin M., Denoix J.-M. (2004) Magnetic resonance imaging of a brain abscess in a 10-month-old filly. Vet. Radiol. Ultrasound 45, 210-215

Bischofberger A. S., Konar M., Posthaus H., Pekarkova M., Grzybowski M., Brehm W. (2008) Ocular angiosarcoma in a pony MRI and histopathological appearance. Equine Vet. Educ. 20, 340-347

Böhme G. (2004) Nickel R., Schummer A. and Seiferle E.: Lehrbuch der Anatomie der Haustiere, Band IV: Nervensystem, Sinnesorgane, Endokrine Drüsen. 4. Aufl., Parey Verlag, Stuttgart

Cavalleri J.-M. V., Metzger J., Hellige M., Lampe V., Stuckenschneider K., Tipold A., Beineke A., Becker K., Distl. O., Feige K. (2013) Morphometric magnetic resonance imaging and genetic testing in cerebellar abiotrophy in Arabian horses. BMC Vet. Res. 9, 105. doi:10.1186/1746-6148-9-105

Chaffin M. K., Walker M. A., McArthur N. H., Perris E. E., Matthews N. S. (1997) Magnetic resonance imaging of the brain of normal neonatal foals. Vet. Radiol. Ultrasound 38, 102-111

Dahme E., Schmahl W., Matiasek K. (2007) Nervensystem, In: Grundriss der speziellen pathologischen Anatomie der Haustiere. Dahme E. and Weiss E. (Hrsg.) 6. Aufl., Verlag Enke, Stuttgart, 267-318

De Zani D., Zani D. D., Binanti D., Riccaboni P., Rondena M., Di Giancamillo M. (2013) Magnetic resonance features of closed head trauma in 2 foals. Equine Vet. Educ. doi:10.1111/ eve. 12003

Deistung A., Biedermann U., Schäfer A., Schweser F., Güllmar D., Trampel R., Turner R., Reichenbach J. R. (2013) MR Imaging of the human brainstem in vivo at 7 Tesla. Poster, 30. Arbeitstagung der Anatomischen Gesellschaft, Würzburg, 2013

Dyson P. K., Dunn K. A., Whitwell K., Dennis R. (2007) Ataxia and cranial nerve signs in a pony suffering a brainstem meningioma; clinical, MRI, gross and histopathological findings. Equine Vet. Educ. 19, 173-178

Ferrell E. A., Gavin P. R., Tucker R. L., Sellon D. C., Hines M. T. (2002) Magnetic resonance for evaluation of neurologic disease in 12 horses. Vet. Radiol. Ultrasound 43, 510-516

Haltaufderheide K. (2009) Darstellung von Hirnnerven im Bereich des Hirnstamms mit dem 3,0 Tesla MRT im Vergleich zum 1,5 Tesla MRT. Dissertation, Medizinische Fakultät Charité - Universitätsmedizin Berlin

Hause F. (2011) Vergleichende Darstellung des Nervus intermediofacialis und seiner Abgänge - Fortschritte in der Bildgebung durch 3Tesla MRT. Dissertation, Friedrich-Schiller Universität Jena

Hecht S., Adams W. H. (2010) MRI of brain disease in veterinary patients part 1: Basic principles and congenital brain disorders. Vet. Clin. North. Am. Small Anim. Pract. 40, 21-38

Holmes S. P. (2013) 8 Equine skull magnetic resonance imaging: The where, when and why? Equine Vet. Educ. doi: 10.1111/eve. 12039
Johnston G. M., Taylor P. M., Holmes M. A., Wood J. L. N. (1995) Confidential enquiry of perioperative equine fatalities (CEPEF-1): Preliminary results. Equine Vet. J. 27, 193-200

Kretschmann H. J., Weinrich W. (2003) Klinische Neuroanatomie und kranielle Bilddiagnostik: Atlas der Magnetresonanztomographie und Computertomographie. 3. Aufl., Verlag Thieme, Stuttgart

Lempe A., Heine M., Bosch B., Mueller K., Brehm W. (2012) Imaging diagnosis and clinical presentation of a Chiari malformation in a Thoroughbred foal. Equine Vet. Educ. 24, 618-623

Leser S., Flatz K., Brühschwein A., May A., Janik D., Matiasek K., Gerhards H. (2013) Magnetic resonance imaging of an equine ependymoma. Pferdeheilkunde 29, 467-470

Maulet B. E. B., Bestbier M., Jose-Cunilleras E., Scrine J. A., Murray $R$. (2008) Magnetic resonance imaging of a cholesterol granuloma and hydrocephalus in a horse. Equine Vet. Educ. 20, 74-79

Mitchell R. D., Edwards R. B., Makreel L. D., Oliveira T. D. (2006) Standing MRI lesions identified in jumping and dressage horses with lameness isolated to the foot. Proc. Am. Assoc. equine Practnrs 52, 422-426

Müller J.-M. V., Hellige M., Hoffmann M. V., Uhlendorf F., Stein-Metz S., Feige K. (2011) Parietaler cerebraler Defekt nach Schädelfraktur als Ursache für eine posttraumatische Epilepsie bei einem Isländerwallach. Pferdeheilkunde 27, 306-310

Naylor R. J., Dunkel B., Dyson S., Paz-Penuelas M. P., Dobson J. (2010) A retrobulbar meningioma as a cause of unilateral exophthalmos and blindness in a horse. Equine Vet. Educ. 22, 503-510

Nomina Anatomica Veterinaria (2012) 5th ed. (Revised edition), International Committee on Veterinary Gross Anatomical Nomenclature, Hannover, Columbia, Ghent, Sapporo. 03.04.2013: http://www.wava-amav.org

Oey L., Müller J.-M. V., Kloppmann T. V., Jacobsen B., Beineke A., Feige K. (2011) Diagnosis of internal and external hydrocephalus in a warmblood foal using magnetic resonance imaging. Tierärztl. Prax. 39, 41-45

Pongratz M. C., Kircher P., Lang J., Hilbe M., Eser M. W. (2010) Diagnostic evaluation of a foal with Cerebellar Abiotrophy using Magnetic Resonance Imaging (MRI). Pferdeheilkunde 26, 559-562

Sanders S. G., Tucker R. L., Bagley R. S., Gavin P. R. (2001) Magnetic resonance imaging features of equine nigropallidal encephalomalacia. Vet. Radiol. Ultrasound 42, 291-296

Schwarzmüller-Erber G., Silberstein E. (2010) Angewandte Magnetresonanztomographie. Grundlagen und Anwendungen. 1. Aufl., Verlag Facultas.wuv, Wien

Spoormakers T. J. R., Ensink J. M., Goehring L. S., Koeman J. R., Ter Braake F., Van Der Vlugt-Meijer R. H., Van Den Belt A. J. M. (2003) Brain abscesses as a metastatic manifestation of strangles: Symptomatology and the use of magnetic resonance imaging as a diagnostic aid. Equine Vet. J. 35, 146-151

Stuckenschneider K. (2013) Magnetresonanztomographische Untersuchungen der Gehirnregion gesunder und neurologisch erkrankter Pferde mit einer Feldstärke von 3 Tesla. Dissertation, Tierärztliche Hochschule Hannover. Cuvillier Verlag Göttingen

Tucker R. L., Sampson S. N. (2007) Magnetic Resonance Imaging Protocols for the Horse. Clin. Tech. Equine Pract. 6, 2-15

Weishaupt D., Köchli V. D., Marincek B., Froehlich J. M. (2009) Wie funktioniert MRI? Eine Einführung in Physik und Funktionsweise der Magnetresonanzbildgebung. 6. Aufl., Verlag Springer Medizin, Heidelberg

This article represents selected parts of the dissertation thesis of Stuckenschneider (2013), University of Veterinary Medicine, Hannover, ISBN: 978-3-95404-495-5 